\title{
Development and Validation of Resource Flexibility Measures for Manufacturing Industry
}

\author{
Gulshan Chauhan ${ }^{1}$, T.P. Singh ${ }^{2}$ \\ ${ }^{1}$ Principal, Panipat Institute of Engineering \& Technology (India) \\ ${ }^{2}$ Director, Symbiosis Institute of Technology (India) \\ chaubanreck@gmail.com, tpmalik@yahoo.com
}

Received: January 2013

Accepted: November 2013

\section{Abstract:}

Purpose: Global competition and ever changing customers demand have made manufacturing organizations to rapidly adjust to complexities, uncertainties, and changes. Therefore, flexibility in manufacturing resources is necessary to respond cost effectively and rapidly to changing production needs and requirements. Ability of manufacturing resources to dynamically reallocate from one stage of a production process to another in response to shifting bottlenecks is recognized as resource flexibility. This paper aims to develop and validate resource flexibility measures for manufacturing industry that could be used by managers/ practitioners in assessing and improving the status of resource flexibility for the optimum utilization of resources.

Design/methodology/approach: The study involves survey carried out in Indian manufacturing industry using a questionnaire to assess the status of various aspects of resource flexibility and their relationships. A questionnaire was specially designed covering various parameters of resource flexibility. Its reliability was checked by finding the value of Cronback alpha (0.8417). Relative weightage of various measures was found out by using Analytical Hierarchy Process (AHP). Pearson's coefficient of correlation analysis was carried out to find out relationships between various parameters.

Findings: From detailed review of literature on resource flexibility, 17 measures of resource flexibility and 47 variables were identified. The questionnaire included questions on all these 
measures and parameters. 'Ability of machines to perform diverse set of operations' and ability of workers to work on different machines' emerged to be important measures with contributing weightage of $20.19 \%$ and $17.58 \%$ respectively. All the measures were found to be significantly correlated with overall resource flexibility except 'training of workers', as shown by Pearson's coefficient of correlation. This indicates that companies do not want to spend on worker training.

Practical implications: The study provides guidelines to managers/ practitioners in assessing and managing resource flexibility for optimum utilization of resources. This study can also help the firm's management to identify the measures and variables to manage resource flexibility and the order in which stress should be given to various measures and actions. The developed and validated measures can be used globally for managing the resource flexibility in manufacturing sector.

Originality/value In this work, the theoretical perspective has been used to prepare the instrument from a detailed review of literature and then the study carried out using the questionnaire in an area where such studies were not carried out earlier.

Keywords: resource flexibility, measures, manufacturing industry, survey, analytical hierarchy process

\section{Introduction}

The approach to manufacturing has undergone a considerable change in the past two decades or so. In today's business world, emphasis is shifting from mass production of low-cost, interchangeable commodities to the production of high-quality goods and services made individually or in small batches to meet the specific demands of small groups of consumers. This shift requires greater flexibility in manufacturing system to accommodate rapid changes in product design as per consumer demand (Wagner \& Hollenbeck, 2010). Today's market is determined by customers. For producers to exist, they must seek and produce what potential consumers require. The customers, these days, have many options available and only that product, which comes up to a customer's expectations may dominate the market. Industrial systems have become very complex owing to a large variety of products being made in a single manufacturing firm. A number of different types of materials, machines, tools, skill levels, and other inputs have to be employed in a production system. Market uncertainties, because of a scarcity of resources and rapid product innovations, add to the decision-making complexities in the manufacturing system (Zapfel, 1998). Achieving higher levels of productivity in this complex environment requires a system to rapidly adjust itself to complexities, uncertainties, and changes. Thus, flexibility is required for productivity. 
Simply stated, flexibility is the ability of a system to react to and accommodate changes (Chauhan \& Singh, 2011). To remain competitive, flexibility must exist during the entire life cycle of a product, from design to distribution (Chauhan, Singh \& Sharma, 2010). Manufacturing flexibility has become an exclusive expression that indicates a manufacturing system's ability to respond to fluctuations in the production process and produce customeroriented products at low cost and greater response sensitivity in dynamically changing manufacturing systems. Flexibility is an inherent attribute and an intangible asset of a manufacturing enterprise. Flexibility is difficult to understand and quantify and is expensive to build (Chauhan, Singh \& Sharma, 2007). Knowledge about its own inherent flexibility helps an enterprise to manage it in a more effective manner towards the organizational performance improvement. Flexibility can be used not only for effectively managing the changes but also for enhancing performance of manufacturing systems (Chen \& Adam, 1991).

To remain competitive, many companies have improved their production processes by introducing manufacturing flexibility (Cox, 1989). The manufacturing flexibility that can only be achieved with flexible resources is termed as resource flexibility. Machines and workforce are the most important resources of a manufacturing organization (Chauhan \& Singh, 2011). Thus, machine and labor flexibility forms the foundation blocks of manufacturing flexibility. Moreover, other types of flexibilities, such as process flexibility, operation flexibility, product flexibility, routing flexibility, and product-mix flexibility depend on labor and machine flexibility (Karuppan \& Ganster, 2004). Resource flexibility has received an increasing amount of popularity in the past two decades as it provides companies with the ability to adhere to disturbances in the production process so that new and existing products can be produced more rapidly.

Resource flexibility follows the organization's community partnerships and quality improvement processes. Using flexibility in the allocation of financial, human and physical resources enables local decisions about objectives and strategies from the partnerships plan to be put into effect. Daniels, Mazzola and Shi (2004) have demonstrated that allocation of partial resource flexibility shows substantial improvements in operational performance in both serial and parallel-machine production environments through the effective utilization of resources. Process divergence and diverse process flows must be considered while taking decisions about resource flexibility. In case of immense task divergence and flexible process flow high level of resource flexibility is required. Accordingly, employees need to perform a broad range of duties, and equipment must be general purpose. Otherwise, utilization will be too low for economical operations (Krajewski, Ritzman \& Malhorta, 2010). Thus, it seems to be important to gain an understanding of how resource flexibility can be managed in manufacturing systems. This paper is focused on the development and validation of resource flexibility measures in Indian manufacturing industry. The paper is structured as follows: in section 2 the manufacturing flexibility definitions and technological attributes defined by previous literature are reviewed. In section 3 , the methodology adopted for the study, resource flexibility construct and details of survey instrument have been presented. Section 4 presents the detailed analysis, results and impact of 
various measures on resource flexibility. Finally, in section 5, conclusions and guidelines for future research with regard to resource flexibility are developed.

\section{Literature Review}

The need and attempts to compute the value of flexibility may be viewed as a hedge against future uncertainty (Sethi \& Sethi, 1990). Also, researchers need flexibility measures to test theories and operation managers need them to facilitate making capital investment decisions and in determining performance levels. Many of the existing flexibility studies have only investigated the concept of flexibility in relation to a particular domain and a specific objective, instead of considering an entire resource flexibility of the system. Gerwin (1987) has highlighted labor, machine, process and routing as the components of manufacturing flexibility. Sarker, Krishnamurthy and Kuthethur (1994) presented measures of machine, process and routing component level flexibility and concluded that it is quite impossible to have a universal scale of overall manufacturing flexibility. As a result, current flexibility models are simply based on a limited analysis of manufacturing systems (Koste \& Malhotra, 1999). Therefore, while there are several taxonomies that attempt to define manufacturing flexibility, they are incomplete or too abstract to explain the fundamental concept of flexibility (Gupta \& Buzacott, 1989; Shewchuk \& Moodie, 1998). Thus, the meaning and implementation of overall resource flexibility still remains ambiguous (Chang, Whitehouse, Chang \& Hsieh, 2001). An analytical model capable of generating a clear relationship between the degree of a system's flexibility and the level of a system's performance has yet to be defined (Slack, 1987; Kumar, 1987; Gupta \& Goyal, 1989). Wahab (2005) proposed a generic model to measure machine and product mix flexibilities with consideration of uncertainties in the system. Manufacturing flexibility is the ability of the organization to manage production resources and uncertainty to meet various customer requests (Zhang, Vonderembse \& Lim, 2003). Manufacturing flexibility is considered to be a strategic element of business, along with price (cost), quality, and dependability (Chauhan \& Singh, 2011). According to Chen and Adam (1991), investment in flexible manufacturing systems leads to various advantages: less scrap, reduced downtime, improved quality, increased labor productivity, better machine efficiency and augmented customer satisfaction etc.

Machine flexibility is dependent on the ease with which one can make changes in order to produce a given set of part types (Browne, Dubois, Rathmill, Sethi \& Stecke, 1984). A multi-skilled workforce is believed to enhance system performance (Treleven, 1989). Jaikumar (1989) has discovered that labor flexibility has proved to be the key to the success of flexible manufacturing systems in Japan. Machine flexibility is measured by the number of operations that a workstation performs and the time needed to switch from one operation to another (Tsourveloudis \& Phillis, 1998). The extent of flexibility can be measured by its metrics; efficiency, responsiveness, versatility and robustness (Golden \& Powell, 2000). Efficiency and 
versatility should be considered for the measurement of machine flexibility (Chang et al., 2001). Operators with a high level of skills should be assigned first and versatile operators last to maximize quality and minimize staffing costs (Franchini, Caillaud, Nguyen \& Lacoste, 2001). A flexible workforce is especially valuable in responding to the design changes and new product introduction. Higher labor flexibility provides enhanced capability to reassign tasks in the case of workforce absence (Singh, 2008).

Resource flexibility in the form of labor and machine flexibility can be judiciously exploited towards reduction in wastages in resources of manufacturing enterprise (Malhotra \& Ritzman, 1990). Resource flexibility helps the firm to reduce manufacturing flow times, work-in-process inventories, and improve customer service while providing an efficient use of both labor and equipment (Polakoff, 1991). Substantial improvements in operational performance can be achieved through scheduling parallel manufacturing cells with effective utilization of resource flexibility (Daniels, Hoopes \& Mazzola, 1996). Every operation may need several resources and furthermore, a resource may be selected from a given set of resources. Peres, Roux and Lasserre (1998) have presented multi-resource shop scheduling with resource flexibility by assigning operations to resources and sequence operations, in order to minimize the completion time. Depending on the amount of internal resources, a group may exit a market in response to increased competition, or channel funds to the subsidiary operating in that market. Resource flexibility within a group makes subsidiaries' reaction functions flatter, thus discouraging rivals' strategic commitments when entry is accommodated (Cestone \& Fumagalli, 2005). A multidimensional flexible methodology has been used to develop resource flexibility measures by integrating a variety of technological aspects within manufacturing systems. In order to capture the dynamic aspect of resource flexibility, different attributes have been considered. The motivation behind the evolved methodology stems from the work of Sarker et al. (1994), in which they presented a survey and critical review of flexibility measures in manufacturing systems and Koste, Malhotra and Sharma (2004) in which various dimensions for the measurement of manufacturing flexibility were covered. This forms the basis for recognition of resource flexibility measures for the present study. The review of literature brings out clearly that machines and labor are two of the most fundamental and important resources of manufacturing industry. Although, isolated methods for measuring machine, labor and product flexibilities have been developed by various researchers (Gerwin, 1987; Sethi \& Sethi, 1990; Chang et al., 2001) yet a generic flexible approach to measure overall resource flexibility of manufacturing firms that incorporates a number of technological attributes in its design is not available and this study attempts at evolving one such approach. The study involves 17 measures contributing to resource flexibility and their 47 variables for measuring resource flexibility in manufacturing organizations. 


\section{Research Methodology}

The research methodology includes an extensive review of literature to identify various constructs of resource flexibility, determining the weightages of these constructs towards resource flexibility through the use of Analytic Hierarchy Process, survey of industry using a specially designed questionnaire which carries questions on various constructs and variables of resource flexibility and analysis of the response of the survey to calculate resource flexibility to validate the approach. The methodology adopted includes the following:

- Development of resource flexibility construct from the review of literature

- Assessing the weightage of different measures of resource flexibility using AHP

- Design of a questionnaire covering questions on various measures of resource flexibility and its pre-testing.

- Collection of data on various measures through survey of manufacturing industry.

- Measurement of resource flexibility and validation of measures by statistical analysis.

\subsection{Development of Resource Flexibility Construct}

Many different types of flexibilities have been identified in the literature and the research indicates that the domain of any flexibility dimension is comprised of four elements: rangenumber, range-heterogeneity, mobility, and uniformity of a system or resource (Slack, 1983, 1987; Upton, 1994; Koste \& Malhotra, 1999). In this study, the focus is on the overall resource flexibility measures that includes machines, labor and products (materials). These resources are frequently studied in the literature (Gupta \& Somers, 1992; Nandkeolyar \& Christy, 1992; Malhotra \& Ritzman, 1990; Chauhan \& Singh, 2011) and also provide a foundation for the development of resource flexibility measures. Resource flexibility is reflected by the ability of the resources to deal with a broad range of manufacturing tasks effectively. Flexible resources are especially valuable in responding to the design changes and new product introduction. Moreover, it has been recognized that adapting to sudden decreases in demand is more difficult than adapting to sudden increase in demand. With flexible workforce, well-trained multifunctional operators can be relocated to reduce set-up and other maintenance costs. Flexible machines deal with the variety of operations without incurring high costs or expending prohibitive amount of time in switching from one operation to another. Flexible machines allow small batch sizes, which, in turn, result in lower inventory costs, higher machine utilization, ability to produce complex parts and improved products quality. The flexible machines and workforce can handle a variety of products also. The resource flexibility has been determined from the response to the variables framed on the following measures: 

a) Ability of workers to work on different machines.
b) Skill level of workers to perform different jobs.
c) Cost effectiveness of workers over job change.
d) Reliability of workers over job change.
e) Attitude of workers towards change.
f) Productivity effectiveness due to change of workforce.
g) Co-operation of workers in achieving production targets.
h) Ability of production workers to perform inspection jobs.
i) Ability of production workers to do autonomous maintenance.
j) Training of workers.
k) Ability of machines to perform diverse set of operations.
I) Ease of machine setup or changeover.
m) Time and effort needed to change the tools and operations.
n) Cost effectiveness of operations over machine change.
o) Productivity effectiveness due to change of machine.
p) Obsolescence rate of machines on introduction of new products.
q) Reliability of machines over job change.

\subsection{Assess the Weightage of Different Measures of Resource Flexibility}

Although various measures, as listed above, contribute towards resource flexibility yet their contribution cannot be assumed equal. Weightage of some measures may be more than others. To determine their relative weightage, the analytical hierarchy process (AHP) was employed (Saaty, 1986; 1990). Each measure is compared with other measures pair-wise. Three experts; one industrial manager, one senior production executive and one academician were involved in the process of paired comparison for determining the weights of various measures. They, however, filled the response in qualitative scale of very low, low, medium, high and very high as the difference between the importances of two measures. These qualitative responses are converted to the quantitative values using the scale as: very low $=1$; 
low $=3$; medium $=5 ;$ high $=7$ and very high $=9$. Position matrices were made, separately for each expert showing the paired comparison of each measure with the other measures. The weightage of each measure was determined by calculating an eigenvector and normalizing it for each expert's response. From the weightages of each measure, calculated in the above manner by each expert, mean weightage was calculated as shown in table 1. A consistency index (CI) and consistency ratio (CR) is also calculated to check the numerical and transitive consistency and validity of experts' judgments for resource flexibility measures.

\begin{tabular}{|c|c|c|c|c|c|}
\hline Measures & $\begin{array}{c}\text { Expert I } \\
\text { Weightage }\end{array}$ & $\begin{array}{l}\text { Expert II } \\
\text { Weightage }\end{array}$ & $\begin{array}{l}\text { Expert III } \\
\text { Weightage }\end{array}$ & $\begin{array}{c}\text { Mean } \\
\text { Weightage }\end{array}$ & $\begin{array}{l}\text { Percentage } \\
\text { Weightage }\end{array}$ \\
\hline a & 0.1728 & 0.1854 & 0.1693 & 0.1758 & 17.58 \\
\hline$b$ & 0.1031 & 0.0557 & 0.0984 & 0.0857 & 8.57 \\
\hline c & 0.0115 & 0.0108 & 0.0217 & 0.0147 & 1.47 \\
\hline d & 0.0558 & 0.0557 & 0.0490 & 0.0535 & 5.35 \\
\hline e & 0.0262 & 0.0234 & 0.0102 & 0.0200 & 2.00 \\
\hline$f$ & 0.0262 & 0.0557 & 0.0217 & 0.0345 & 3.45 \\
\hline $\mathrm{g}$ & 0.0114 & 0.0234 & 0.0217 & 0.0189 & 1.89 \\
\hline $\mathrm{h}$ & 0.0262 & 0.0234 & 0.0490 & 0.0329 & 3.29 \\
\hline $\mathrm{i}$ & 0.0558 & 0.0557 & 0.0490 & 0.0535 & 5.35 \\
\hline$j$ & 0.0114 & 0.0108 & 0.0102 & 0.0108 & 1.08 \\
\hline $\mathrm{k}$ & 0.2024 & 0.1943 & 0.2091 & 0.2019 & 20.19 \\
\hline 1 & 0.0121 & 0.0183 & 0.0255 & 0.0186 & 1.86 \\
\hline $\mathrm{m}$ & 0.0498 & 0.0424 & 0.0255 & 0.0392 & 3.92 \\
\hline$n$ & 0.0226 & 0.0183 & 0.0128 & 0.0179 & 1.79 \\
\hline 0 & 0.0497 & 0.0491 & 0.0563 & 0.0517 & 5.17 \\
\hline$p$ & 0.0899 & 0.0951 & 0.1146 & 0.0999 & 9.99 \\
\hline$q$ & 0.0736 & 0.0828 & 0.0563 & 0.0709 & 7.09 \\
\hline
\end{tabular}

Table 1 . Weightage of resource flexibility measures

The most important measures of resource flexibility were found to be "ability of machines to perform diverse set of operations" and "ability of workers to work on different machines", with a contributing weightage of $20.19 \%$ and $17.58 \%$ respectively. These are followed by "obsolescence rate of machines on introduction of new products", "skill level of workers to perform different jobs", "reliability of machines over job change", "reliability of workers over job change", "ability of production workers to do autonomous maintenance" and "productivity effectiveness due to change of machine" with contributing weight of $9.99 \%, 8.57 \%, 7.09 \%$, $5.35 \%, 5.35 \%$ and $5.17 \%$ respectively. Other measures have a contribution of less than five percent as shown in table 1 . They are comparatively less important in the measurement of resource flexibility. 


\subsection{Design of Questionnaire}

Questions were framed on all 17 constructs and 47 variables. Each question had a multiple choice answer and a seven point Likert scale ranging from strongly agree to strongly disagree with a middle point anchor of neither agree nor disagree. To ensure the relevance and effectiveness of questions to the industry, the questionnaire was pre-tested on a random sample of 12 units and the suggestions received are incorporated. Internal reliability of questionnaire items is tested by calculating Cronbach's alpha using the IBM SPSS 11.01 software. Cronbach's alpha is a coefficient of reliability. It is commonly used as a measure of the internal consistency or reliability and validation of measurement instruments such as questionnaires. It was first named alpha by Cronbach (1951). The survey questionnaire is found to be acceptable, with a Cronbach's alpha equal to 0.8417 (Radhakrishna, 2007).

\subsection{The Survey of Manufacturing Industry}

The survey was carried out in Indian manufacturing industry. A manufacturing firm is likely to reflect, to some degree all seventeen measures of resource flexibility included in the study. Considering that the targeted survey respondent should possess adequate knowledge to complete the instrument, which included resource flexibility measures within the responsibility of top management, plant managers or senior executives of manufacturing systems were the target respondents. Manufacturing firms of a reasonable size (medium to large) were chosen for the survey. To meet these needs, the automobile, automotive parts, machinery and metal part industries were selected by referring to the Directory of Industries 2009. The final survey instrument was mailed to 186 organizations in the sample frame along with a write-up on the objective of the survey and its usefulness for the industry in the states of Haryana, Himachal Pradesh, Uttarakhand, Uttar Pradesh and the National Capital Region of India. These industries produce a wide range of products, such as tractors, machine tools, cycles, auto parts, pressure vessels, presses, electrical and construction machinery, plant and machinery for cement, paper and sugar, and a large number of other industrial and consumer goods. In spite of all efforts, 52 responses were received, resulting in a response rate of 27.96 percent "which is satisfactory in comparison with other empirical research" (Hyer \& Wemmerlov, 1989; Sethi \& King, 1994; Koste et al. 2004) and is considered acceptable in operations management survey research (Malhotra \& Grover, 1998). Out of 186 units to whom the questionnaire was sent, 142 were private sector firms and 44 public sector firms. Out of the responding firms, 34 were private sector and 18 public sector firms. Analyzing it scale-wise, the response from large scale firms is $37.03 \%$ and from medium scale is $24.24 \%$. The response of the survey was compiled and analysed to calculate the value of each construct for the surveyed industry 


\subsection{Measurement of Resource Flexibility}

Each question has seven options for the answer and thus a score between 1 and 7 is possible. Thus each question can have a highest score of 7 and each construct a score of $7 * n$ (where $n$ is the number of variables in each measure). Actual score received by a construct is divided by the maximum possible score to calculate value of each measure on a scale of 0 to 1 . To calculate the value of each measure from the raw scores of the questionnaire and the status of resource flexibility following equations were used:

$$
\text { Value of } i^{\text {th }} \text { Measure }\left(R F_{i}\right)=\frac{\sum S a i}{n S m}
$$

Where $\sum S_{a} i$ is the sum of actual score of $i^{\text {th }}$ measure, which is further equal to:

$$
\sum \text { Sai }=S_{1}+S_{2}+\ldots+S_{n}
$$

Where $\mathrm{n}$ is the number of variables in a measure, and $\mathrm{Sm}$ is the maximum possible score for a variable (i e. 7):

$$
\text { Resource Flexibility }(R F)=\sum_{i=0}^{n} R F_{i} * W F_{i}
$$

Where $R F_{i}$ is the value of $i_{t h}$ measure of resource flexibility and $W F_{i}$ is its weightage calculated from AHP.

Actual score of each measure is found by adding the score of various variables under that measure as shown in Equation 2. Values of each measure are calculated by dividing the actual score with the maximum possible score of that measure using Equation 1. Finally status of resource flexibility is computed by addition of product of value and contributing weight of each measure as illustrated in Equation 3.

\section{Results and Discussion}

The highest value, lowest value and average value of resource flexibility among the surveyed companies are $0.8430,0.4812$ and 0.6476 respectively. The average value shows that the status of resource flexibility in most of the firms is not very good. Thus there is need of understanding the importance of resource flexibility. There are only two units with a score of above 0.80 . There are 11 more units that have a score between 0.70 and 0.75 and can be termed as good. At the other extreme thirteen units are below a score of 0.60 . These can be termed poor from a resource flexibility point of view.

Pearson's coefficients of correlations between various measures of resource flexibility are worked out using SPSS 11.01. Pearson's coefficient of correlation ( $r$ ) is a measure of the strength of the association between two variables. It can have a value anywhere between plus and minus one. The larger the value of ' $r$ ', ignoring the sign, the stronger would be the association between the two variables and the more accurately one can predict one variable from the knowledge of the other. At its extreme, a correlation of 1 or -1 means that the two variables are perfectly correlated, 
meaning that one can predict the values of one variable from the values of the other variable with perfect accuracy. At the other extreme, zero value of ' $r$ ' implies an absence of correlation, i.e. there is no relationship between the two variables. The value of Pearson's coefficient of correlation between various measures and overall resource flexibility are presented in table 2. Table 2 shows that all correlations are positive, i.e. change in any one measure affects all the other measures and overall resource flexibility directly. A total of 272 correlations are determined, of which 224 emerged to be significant. Further, 192 of these correlations are significant at a level of $p \leq 0.01$ and 32 at a level of $p \leq 0.05$. This reflects that all measures of resource flexibility are complementary to each other. If an improvement is made in one the others also get improved. To validate the resource flexibility measures, their relationship with overall resource flexibility are also worked out and their relative impact on resource flexibility is shown in Figure 1. As can be seen, the main measures that influence the realization of resource flexibility are "productivity effectiveness due to change of workforce", "ability of workers to work on different machines", "ability of machines to perform diverse set of operations", "productivity effectiveness due to change of machine" and "cost effectiveness of workers over job change" with an impact factor of $78.2 \%, 76.3 \%, 72.8 \%, 70.5 \%$ and $70 \%$ respectively. It is surprising to find that "training of workers" is having a minimum impact of $9.3 \%$ to implement resource flexibility.

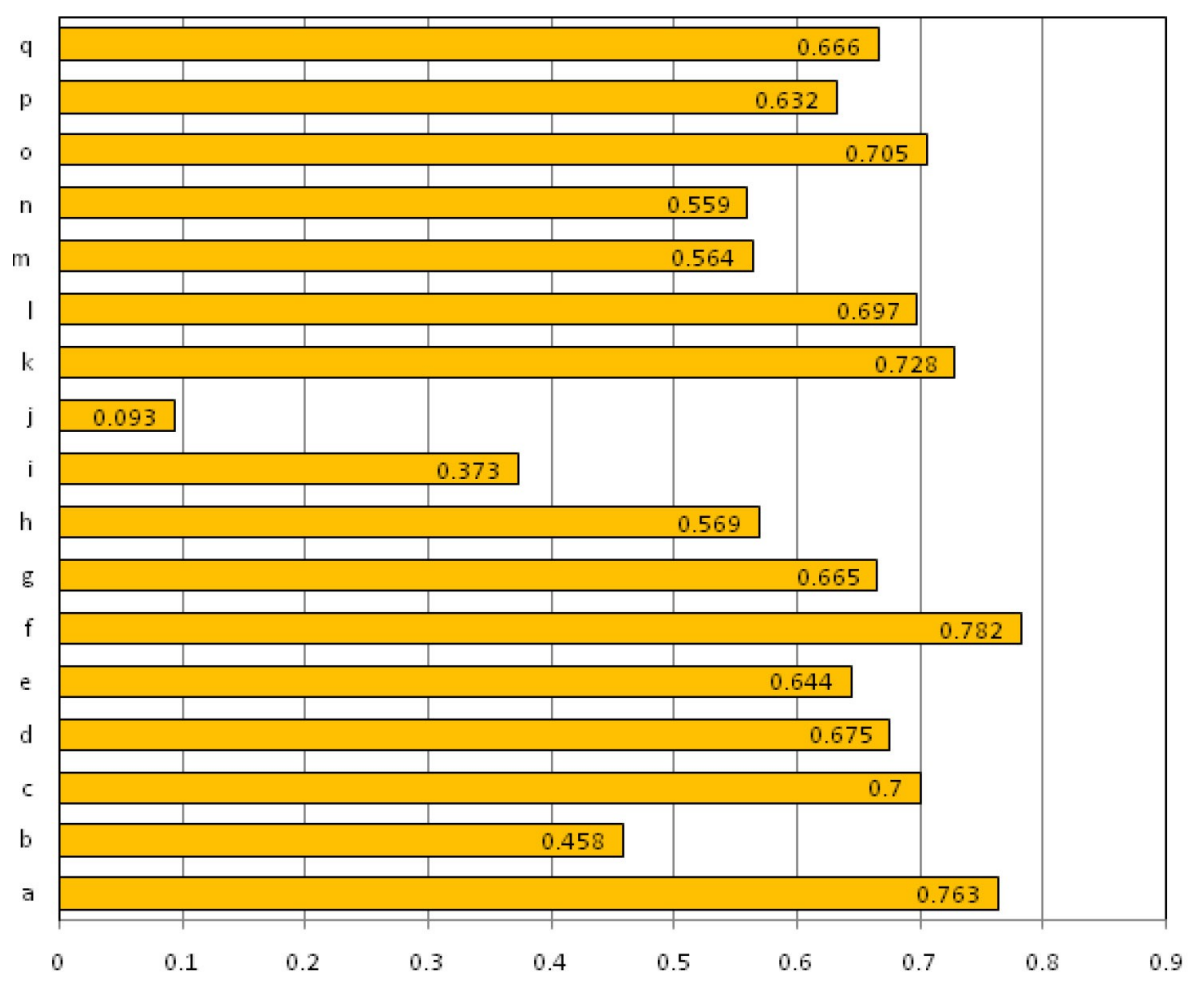

Figure 1. Impact of various measures of resource flexibility 


\begin{tabular}{|c|c|c|c|c|c|c|c|c|c|c|c|c|c|c|c|c|c|c|c|}
\hline$\stackrel{u}{\alpha}$ & 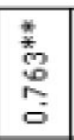 & 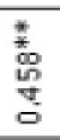 & 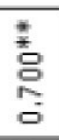 & 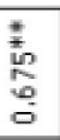 & 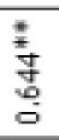 & 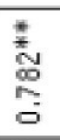 & 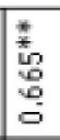 & 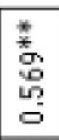 & 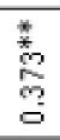 & 奇 & 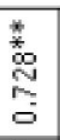 & 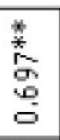 & 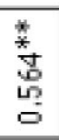 & $\begin{array}{l}\text { 蒡 } \\
\text { 品 } \\
\text { 品 }\end{array}$ & 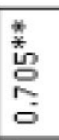 & 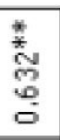 & 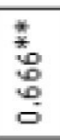 & $\rightarrow$ & \\
\hline$\sigma$ & 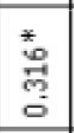 & $\stackrel{g}{\stackrel{g}{g}}$ & 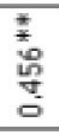 & $\stackrel{ }{\vec{\prime}}$ & 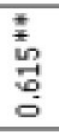 & 曾 & 紊 & 尊 & $\begin{array}{l}\stackrel{*}{*} \\
\stackrel{*}{*} \\
\stackrel{g}{g} \\
g\end{array}$ & 总 & 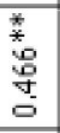 & 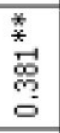 & $\stackrel{*}{\mathrm{\Xi}}$ & $\begin{array}{l}\stackrel{*}{*} \\
\stackrel{*}{*} \\
\stackrel{5}{5} \\
\end{array}$ & 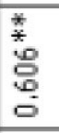 & 罒 & $\rightarrow$ & 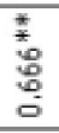 & \\
\hline$a$ & $\begin{array}{l}\text { 今. } \\
\text { 䯧 } \\
0\end{array}$ & $\stackrel{\text { N్ }}{\mathrm{O}}$ & 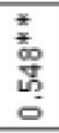 & 嘎 & $\underset{N}{\mathbb{N}}$ & 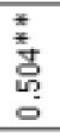 & 鸢 & $\begin{array}{l}\stackrel{9}{\mathrm{~s}} \\
\mathrm{~N} \\
\mathrm{~g}\end{array}$ & $\underset{\mathrm{g}}{\mathrm{g}}$ & 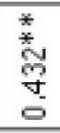 & 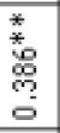 & 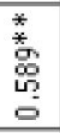 & 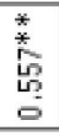 & 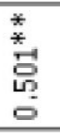 & 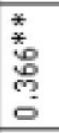 & $\rightarrow$ & 总 & 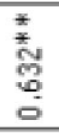 & \\
\hline$\circ$ & 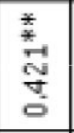 & ్ㅗㅇ & 美 & 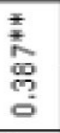 & 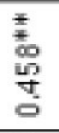 & 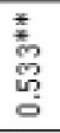 & 苞 & 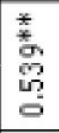 & 恶 & 兽 & 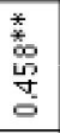 & 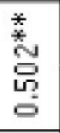 & $\begin{array}{l}\stackrel{*}{*} \\
\stackrel{0}{\mathrm{~g}} \\
\mathrm{~g}\end{array}$ & 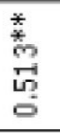 & $\rightarrow$ & $\begin{array}{l}\text { 羔 } \\
\text { 总 } \\
\text { 总 } \\
\end{array}$ & 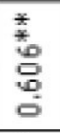 & 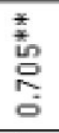 & \\
\hline$=$ & $\begin{array}{l}g \\
\mathrm{~g} \\
\mathrm{~g}\end{array}$ & $\stackrel{\text { 염 }}{\mathrm{g}}$ & 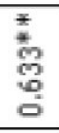 & 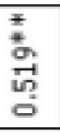 & 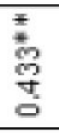 & 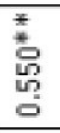 & 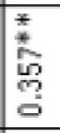 & 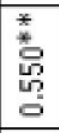 & 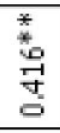 & $\stackrel{8}{8}$ & 롱 & 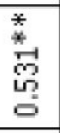 & 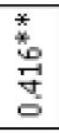 & $\rightarrow$ & 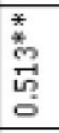 & 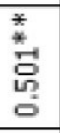 & 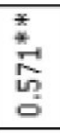 & 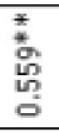 & \\
\hline$E$ & $\begin{array}{l} \\
\text { 恶 } \\
\text { 尃 } \\
\end{array}$ & $\begin{array}{l}\text { 寻 } \\
\end{array}$ & 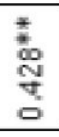 & 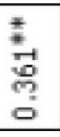 & 总 & $\begin{array}{l} \\
0 \\
0 \\
0 \\
0 \\
0\end{array}$ & 章 & $\begin{array}{l}3 \\
8 \\
\end{array}$ & 름 & $\begin{array}{l}5 \\
\stackrel{2}{2} \\
\end{array}$ & $\begin{array}{l}\text { 总 } \\
\text { g } \\
\end{array}$ & 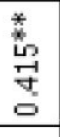 & $r$ & 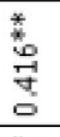 & $\begin{array}{l}\stackrel{*}{\vec{D}} \\
\stackrel{\mathrm{g}}{\mathrm{g}} \\
\mathrm{g}\end{array}$ & 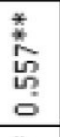 & ले & 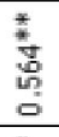 & $\frac{9}{n}$ \\
\hline- & 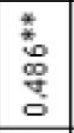 & 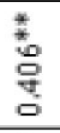 & 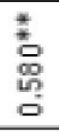 & 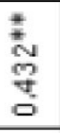 & 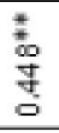 & 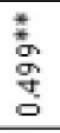 & 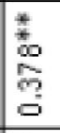 & $\begin{array}{l}\mathbb{N} \\
\mathrm{J}\end{array}$ & $\begin{array}{l}\mathscr{g} \\
\stackrel{g}{g} \\
g\end{array}$ & 总 & 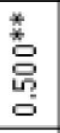 & $r$ & 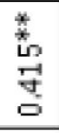 & 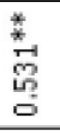 & 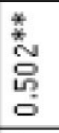 & $\begin{array}{l}\text { 絭 } \\
\text { 品 } \\
\text { 吕 } \\
\end{array}$ & 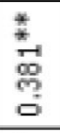 & 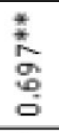 & $\stackrel{0}{\stackrel{0}{0}}$ \\
\hline$\simeq$ & 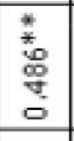 & 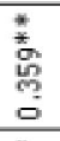 & 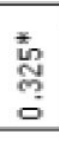 & $\begin{array}{l}\text { № } \\
\text { w } \\
\text { d } \\
\end{array}$ & 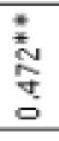 & 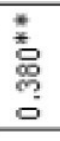 & 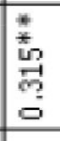 & $\begin{array}{l}\text { 总 } \\
\end{array}$ & 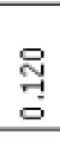 & $\begin{array}{l}\text { 总 } \\
\text { 总 }\end{array}$ & $\rightarrow$ & 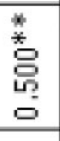 & 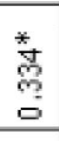 & 롱 & 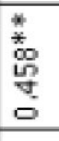 & 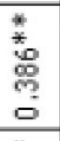 & 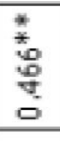 & 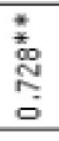 & $\omega$ \\
\hline- & $\begin{array}{l}8 \\
\stackrel{8}{0} \\
0\end{array}$ & 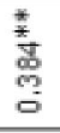 & 誉 & $\begin{array}{l}\text { W } \\
\stackrel{N}{6}\end{array}$ & 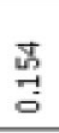 & $\begin{array}{l}\mathbb{N} \\
\stackrel{-1}{G}\end{array}$ & 荨 & 基 & 奇 & $r$ & 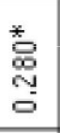 & $\stackrel{8}{g}$ & 总 & $\stackrel{\mathrm{g}}{\mathrm{g}}$ & 吕 & 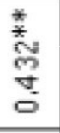 & $\begin{array}{l}\stackrel{8}{\circ} \\
\stackrel{0}{0}\end{array}$ & g & $\stackrel{\varrho}{=}$ \\
\hline- & $\overrightarrow{\mathrm{g}}$ & 兽 & 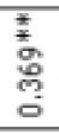 & 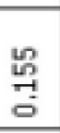 & 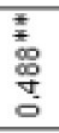 & 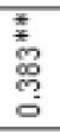 & 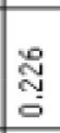 & 尊 & $\rightarrow$ & 总 & $\begin{array}{l}\stackrel{ }{\mathrm{I}} \\
\stackrel{g}{\circ}\end{array}$ & 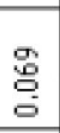 & $\overrightarrow{\mathrm{g}}$ & 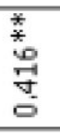 & 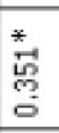 & 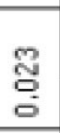 & 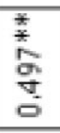 & 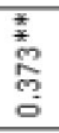 & $\underline{\underline{a}}$ \\
\hline ᄃ & $\begin{array}{l}x_{0} \\
\text { 心 } \\
0\end{array}$ & 렁 & 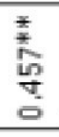 & 荘 & 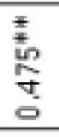 & 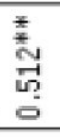 & 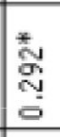 & $\rightarrow$ & 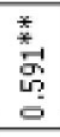 & 喜 & $\begin{array}{l}\text { 总 } \\
\mathrm{g}\end{array}$ & 岂 & $\begin{array}{l}.80 \\
.8 \\
0\end{array}$ & $\begin{array}{l}\text { 盖 } \\
\text { 品 } \\
\text { 品 }\end{array}$ & 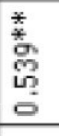 & $\begin{array}{l}\stackrel{\infty}{\circ} \\
\stackrel{8}{\mathrm{c}} \\
\mathrm{c}\end{array}$ & 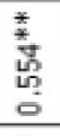 & 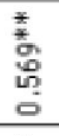 & \\
\hline 0 & 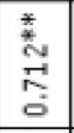 & 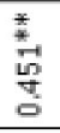 & 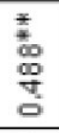 & 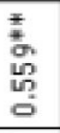 & 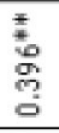 & 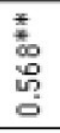 & $\rightarrow-1$ & 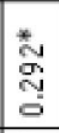 & $\stackrel{\Xi}{\mathrm{J}}$ & 昌 & 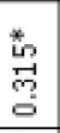 & 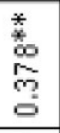 & $\begin{array}{l}\stackrel{*}{*} \\
\stackrel{*}{0} \\
\stackrel{g}{0}\end{array}$ & 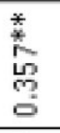 & 䓵 & 总 & $\begin{array}{l}\stackrel{*}{*} \\
\stackrel{*}{*} \\
\stackrel{g}{0}\end{array}$ & 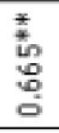 & 蒙 \\
\hline \pm & 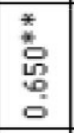 & $\begin{array}{l}\stackrel{8}{\circ} \\
\stackrel{2}{8} \\
\end{array}$ & 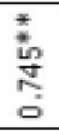 & 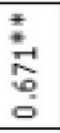 & 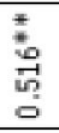 & -1 & 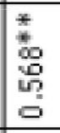 & 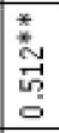 & 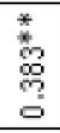 & $\begin{array}{l}\mathrm{N} \\
\mathrm{J} \\
\end{array}$ & 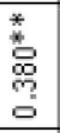 & $\begin{array}{l} \\
\text { 恶 } \\
\text { 尃 } \\
\end{array}$ & $\begin{array}{l} \\
* \\
0 \\
0 \\
0 \\
0 \\
0\end{array}$ & 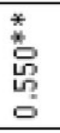 & 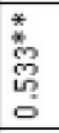 & 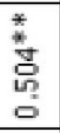 & 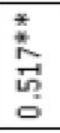 & 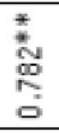 & \\
\hline (1) & 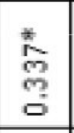 & 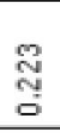 & 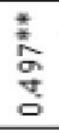 & 嵒 & $\rightarrow$ & 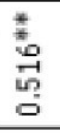 & 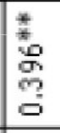 & 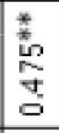 & 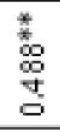 & $\begin{array}{l}\text { 志 } \\
\text { 总 }\end{array}$ & 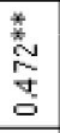 & 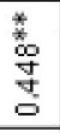 & 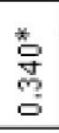 & 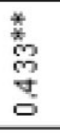 & $\begin{array}{l}\text { 嘉 } \\
\text { 品 } \\
\text { 尃 } \\
\end{array}$ & $\underset{\mathrm{N}}{\mathrm{O}}$ & 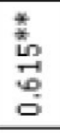 & 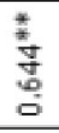 & \\
\hline T & 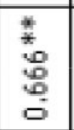 & $\stackrel{\mathrm{d}}{\mathrm{g}}$ & 意 & -1 & 嵒 & 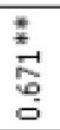 & 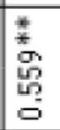 & 挡 & 蛋 & 总 & 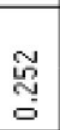 & 焉 & $\begin{array}{l}\stackrel{*}{*} \\
\stackrel{0}{0} \\
0 \\
\square\end{array}$ & 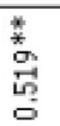 & 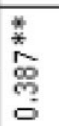 & 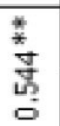 & 总 & 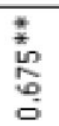 & \\
\hline
\end{tabular}

\begin{tabular}{|c|c|c|c|c|c|c|c|c|c|c|c|c|c|c|c|c|c|c|}
\hline & & & 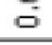 & -1 & 0 & $\circ$ & 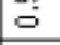 & 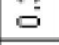 & 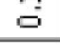 & $\boldsymbol{\theta}$ & 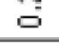 & $=$ & 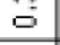 & 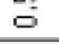 & 8 & 0 & 0 & $\square$ \\
\hline 0 & 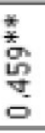 & 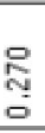 & $\rightarrow$ & 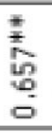 & 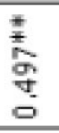 & 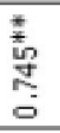 & 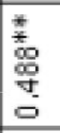 & 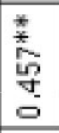 & 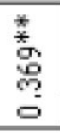 & $\begin{array}{l}\text { 导 } \\
\text { 晋 }\end{array}$ & 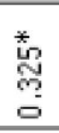 & 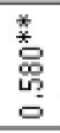 & $\begin{array}{l}\text { 羍 } \\
\text { o } \\
\text { J } \\
g\end{array}$ & 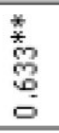 & 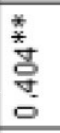 & 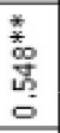 & $\begin{array}{l}\text { 密 } \\
\text { 号 } \\
\text { 号 }\end{array}$ & 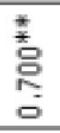 \\
\hline هـ & $\begin{array}{l}\text { 美 } \\
\text { 骂 } \\
\end{array}$ & $\rightarrow$ & 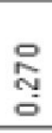 & $\stackrel{\mathbb{N}}{\mathbb{0}}$ & $\stackrel{\mathbb{N}}{\mathbb{N}}$ & 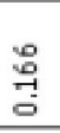 & 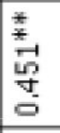 & $\stackrel{\vec{\Xi}}{\mathrm{g}}$ & 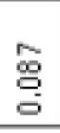 & $\begin{array}{l}\text { 美 } \\
\text { 站 } \\
\text { 今 }\end{array}$ & 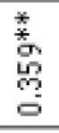 & $\begin{array}{l}\text { 美 } \\
\text { 営 } \\
\text { 。 }\end{array}$ & $\begin{array}{l} \pm \\
\stackrel{7}{g} \\
\end{array}$ & 管 & $\mathrm{g}$ & $\stackrel{\stackrel{N}{N}}{\circ}$ & $\begin{array}{l}0 \\
\overrightarrow{0} \\
0 \\
0\end{array}$ & 0 \\
\hline$\pi$ & $\vec{r}$ & 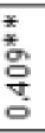 & 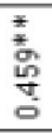 & 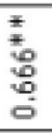 & 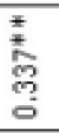 & 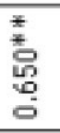 & 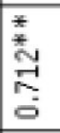 & $\begin{array}{l}\text { 总 } \\
\text { 号 }\end{array}$ & 莺 & $\begin{array}{l}\stackrel{8}{\circ} \\
\text { 금 }\end{array}$ & 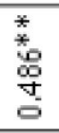 & 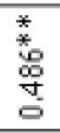 & 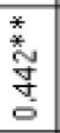 & 怘 & 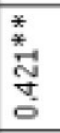 & 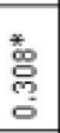 & $\begin{array}{l}\text { 总 } \\
\text { c. } \\
\end{array}$ & $*$ \\
\hline$\frac{\mathscr{w}}{\mathrm{b}}$ & $\approx$ & مـ & 0 & $\pi$ & (D) & 4 & ם & 上 & $=$ & $=$ & $\underline{x}$ & $=$ & $E$ & ᄃ & 0 & $a$ & $\square$ & \\
\hline
\end{tabular}




\section{Conclusion}

Resource flexibility is a polymorphous phenomenon visualized as a means to meet customers' demand quickly, provide a broad product range or introduce new products to the range easily. The present study shows that most of the respondent firms have some level of resource flexibility. 'Productivity effectiveness due to change of manpower' and 'ability of workers to work on different machines' are found to be the leading measures of resource flexibility. Other measures which have been found to be at good level are ability of machines to perform diverse set of operations, productivity effectiveness due to change of machine, cost effectiveness of workers over job change, ease of machine setup or changeover, reliability of workers over job change, reliability of machines over job change, co-operation of workers in achieving production targets, attitude of workers towards change and obsolescence rate of machines on introduction of new products. However, the least practiced measure is training of workers, which indicates that companies do not want to spend on worker training.

In this study an approach has been developed involving 17 measures along with their weightages to build resource flexibility in a manufacturing organization. The approach has been applied through a survey of the industry and validated. The practitioners and managers can make use of the results of this study for managing resource flexibility in their organizations to survive in the present competitive scenario. Further, it was seen that all the measures are significantly correlated with overall resource flexibility except training of workers, as shown by Pearson's coefficient of correlation. The values of correlations provide guidelines to the manufacturing organizations to decide the hierarchy of measures for implementation. The study also concludes the human resource should be taken care off first, followed by machines and products for managing the resource flexibility in Indian manufacturing industry. The study has been limited to manufacturing industry. Future research can focus on resource flexibility in other areas like offices, finance, marketing, process industry and service industry..

\section{References}

Browne, J., Dubois, D., Rathmill, K., Sethi, S.P. \& Stecke, K.E. (1984). Classification of flexible manufacturing systems. F.M.S. Magazine, 2(2), 114-117.

Cestone, G. \& Fumagalli, C. (2005). The strategic impact of resource flexibility in business groups. The RAND Journal of Economics, 36(1), 193-214.

Chang, A.Y., Whitehouse, D.J., Chang, S.L. \& Hsieh, Y.C. (2001). An approach to the measurement of single-machine flexibility. International Journal of Production Research, 39, 1589-1601. http://dx.doi.org/10.1080/00207540010023024 
Chauhan, G., Singh, T.P., \& Sharma, S.K. (2007). Flexibility In Manufacturing Systems: A Study, Proceedings of the All India Conference on Recent Developments in Manufacturing \& Quality Management, 5-6 October, PEC Chandigarh, 16-21.

Chauhan, G., Singh, T.P., \& Sharma, S.K. (2010). Change processes towards flexible lean manufacturing: a framework. International Journal of Performability Engineering, 6(4), 363372.

Chauhan, G., \& Singh, T.P. (2011). Lean manufacturing through management of labor and machine flexibility: a comprehensive review. Global Journal of Flexible Management System, 12(1-2), 69-90.

Chen, F.F., \& Adam Jr., E.E. (1991). The impact of flexible manufacturing systems on productivity and quality. IEEE Transactions on Engineering Management, 38(1), 33-45. http://dx.doi.org/10.1109/17.65758

Cox, T. (1989). Toward the measurement of manufacturing flexibility. Production and Inventory Management Journal, 30(1), 68-72.

Cronbach, L.J. (1951). Coefficient alpha and the internal structure of tests. Psychometrica, 16, 297-334. http://dx.doi.org/10.1007/BF02310555

Daniels, R.L., Hoopes, B.J., \& Mazzola, J.B. (1996). Scheduling parallel manufacturing cells with resource flexibility. Management Science, 42(9), 1260-1276. http://dx.doi.org/10.1287/mnsc.42.9.1260

Daniels, R.L., Mazzola, J.B., \& Shi, D. (2004). Flow shop scheduling with partial resource flexibility. Management Science, 50(5), 658-669. http://dx.doi.org/10.1287/mnsc.1040.0209

Franchini, L., Caillaud, E., Nguyen, P., \& Lacoste, G. (2001). Workload control of human resources to improve production management. International Journal of Production Research, 39(7), 1385-1403. http://dx.doi.org/10.1080/00207540010022322

Gerwin, D. (1987). An agenda for research on the flexibility of manufacturing process. International Journal of Operations and Production Management, 7(1), 38-49. http://dx.doi.org/10.1108/eb054784

Golden, W., \& Powell, P. (2000). Towards a definition of flexibility: in search of the holy grail. Omega, 28(4), 373-384. http://dx.doi.org/10.1016/S0305-0483(99)00057-2

Gupta, D., \& Buzacott, J.A. (1989). A framework for understanding flexibility of manufacturing system. Journal of Manufacturing Systems, 8, 89-97. http://dx.doi.org/10.1016/02786125(89)90028-9 
Gupta, Y.P., \& Goyal, S. (1989). Flexibility of manufacturing system: concept and measurement. European Journal of Operational Research, 43, 119-135. http://dx.doi.org/10.1016/0377-2217(89)90206-3

Gupta, Y.P., \& Somers, T.M. (1992). The measurement of manufacturing flexibility. European Journal of Operational Research, 60(2), 166-182. http://dx.doi.org/10.1016/0377-2217(92)90091-M

Hyer, N.L., \& Wemmerlov, U. (1989). Group technology in the US manufacturing industry: a survey of current practices. International Journal of Production Research, 27(8), 1287-1304. http://dx.doi.org/10.1080/00207548908942623

Jaikumar, R. (1989). Japanese flexible manufacturing systems impact on the United States. Japan and the World Economy, 1(2), 113-143. http://dx.doi.org/10.1016/0922-1425(89)90006-6

Karuppan, C.M., \& Ganster, D.C. (2004). The labor-machine dyad and its influence on mix flexibility. Journal of Operations Management, 22(6), 533-556. http://dx.doi.org/10.1016/j.jom.2004.08.005

Koste, L.L., \& Malhotra, M.K. (1999). A theoretical framework for analyzing the dimensions of manufacturing flexibility. Journal of Operations Management, 18, 75-93. http://dx.doi.org/10.1016/S0272-6963(99)00010-8

Koste, L.L., Malhotra, M.K., \& Sharma, S. (2004). Measuring dimensions of manufacturing flexibility. Journal of Operations Management, 22(2), 171-196. http://dx.doi.org/10.1016/j.jom.2004.01.001

Krajewski, L., Ritzman, L., \& Malhotra, M. (2010). Operations management: processes and supply chains. 9th edition, N. J.: Prentice Hall.

Kumar, V. (1987). Entropic measures of manufacturing flexibility. International Journal of Production Research, 25, 957-966. http://dx.doi.org/10.1080/00207548708919888

Malhotra, M.K., \& Ritzman, L.P. (1990). Resource flexibility issues in multistage manufacturing. Decision Sciences, 21(4), 673-690. http://dx.doi.org/10.1111/j.1540-5915.1990.tb01243.x

Malhotra, M.K., \& Grover, V. (1998). An assessment of survey research in POM: from constructs to theory. Journal of Operations Management, 16, 407-425. http://dx.doi.org/10.1016/S0272-6963(98)00021-7

Nandkeolyar, P., \& Christy, D.P. (1992). Evaluating the design of flexible manufacturing systems. International Journal of Flexible Manufacturing Systems, 4(3-4), 267-292. http://dx.doi.org/10.1007/BF01324883

Peres, S.D., Roux, W., \& Lasserre, J.B. (1998). Multi-resource shop scheduling with resource flexibility. European Journal of Operational Research, 107(2), 289-305. http://dx.doi.org/10.1016/S0377-2217(97)00341-X 
Polakoff, J.C. (1991). Reducing manufacturing costs by reducing cycle time. Corporate Controller, 4(2), 62-64.

Radhakrishna, R.B. (2007). Tips for developing and testing questionnaires/instruments. Journal of Extension, [On-line], 45(1), article 1TOT2, available at: http://www.joe.org/joe/2007february/tt2.php

Saaty, T.L. (1986). Axiomatic foundation of the analytical hierarchy process. Management Science, 32(7), 841-855. http://dx.doi.org/10.1287/mnsc.32.7.841

Saaty, T.L. (1990). How to make a decision: the analytical hierarchy process. European Journal of Operations Research, 48, 9-28. http://dx.doi.org/10.1016/0377-2217(90)90057-I

Sarker, B.R., Krishnamurthy, S., \& Kuthethur, S.G. (1994). A survey and critical review of flexibility measures in manufacturing systems. Production Planning and Control, 5, 512-523. http://dx.doi.org/10.1080/09537289408919525

Sethi, A.K., \& Sethi, S.P. (1990). Flexibility in manufacturing: a survey. International Journal of Flexible Manufacturing Systems, 2(4), 289-328. http://dx.doi.org/10.1007/BF00186471

Sethi, V., \& King, W.R. (1994). Development of measures to assess the extent to which an information technology application provides competitive advantage. Management Science, 40(12), 1601-1627. http://dx.doi.org/10.1287/mnsc.40.12.1601

Shewchuk, J.P., \& Moodie, C.L. (1998). Definition and classification of manufacturing flexibility types and measures. International Journal of Flexible Manufacturing Systems, 10, 325-349. http://dx.doi.org/10.1023/A:1008062220281

Singh, T.P. (2008). Role of manpower flexibility in lean manufacturing. Proceedings of GLOGIFT-2008, Hoboken, NJ: Stevens Institute of Technology. 161-168.

Slack, N. (1983). Flexibility as a manufacturing objective. International Journal of Operations and Production Management, 3(3), 4-13. http://dx.doi.org/10.1108/eb054696

Slack, N. (1987). The flexibility of manufacturing systems. International Journal of Operations and Production Management, 7(4), 35-45. http://dx.doi.org/10.1108/eb054798

Treleven, M. (1989). A review of the dual resource constrained system research. IIE Transactions, 21(3), 279-287. http://dx.doi.org/10.1080/07408178908966233

Tsourveloudis, N.C., \& Phillis, Y.A. (1998). Fuzzy assessment of machine flexibility. IEEE Transactions on Engineering Management, 45(1), 78-88. http://dx.doi.org/10.1109/17.658664

Upton, D.M. (1994). The management of manufacturing flexibility. California Management Review, 36(2), 72-90. http://dx.doi.org/10.2307/41165745 
Wagner, J.A., \& Hollenbeck, J. R. (2010). Organizational Behavior: Securing Competitive Advantage. New York: Routledge.

Wahab, M.I.M. (2005). Measuring machine and product mix flexibilities of a manufacturing system. International Journal of Production Research, 43, 3773-3786. http://dx.doi.org/10.1080/00207540500147091

Zhang, Q., Vonderembse, M.A., \& Lim, J.S. (2003). Manufacturing flexibility: defining and analyzing relationships among competence, capability, and customer satisfaction. Journal of Operations Management, 21, 173-191. http://dx.doi.org/10.1016/S0272-6963(02)00067-0

Zapfel, G. (1998). Customer-order-driven production: An economical concept for responding to demand uncertainty. International Journal of Production Economics, 56, 699-709. http://dx.doi.org/10.1016/S0925-5273(97)00080-7

\section{Annex 1}

\section{Sample Questionnaire}

This questionnaire has been developed into two sections. Section 1 seeks general information of the industrial units. Section 2 seeks information on the measures of resource flexibility.

\section{SECTION: I}

Name of Industry

Address

Total no. manpower :

Size of Industry

Sector

: Private or Public

Products

\section{SECTION: II}

Please tick $(\sqrt{ })$ the appropriate box on a scale of 1 (strongly disagree) to 7 (strongly agree) and middle point of 4 (neither agree nor disagree).

\section{a) Ability of workers to work on different machines.}

1. Workers are responsible for more than one task.

\begin{tabular}{|l|l|l|l|l|}
\hline 1 & 2 & 5 & 5 & 7 \\
\hline
\end{tabular}

2. A large number of job classifications exist in the workforce.

\begin{tabular}{|l|l|l|l|l|}
\hline 1 & 2 & 4 & 5 & 6 \\
\hline
\end{tabular}


3. The tasks which workers perform are not very similar to one another.

\begin{tabular}{|l|l|l|l|l|}
\hline 1 & 2 & 5 & 5 & 7 \\
\hline
\end{tabular}

4. Workers perform a diverse set of tasks.

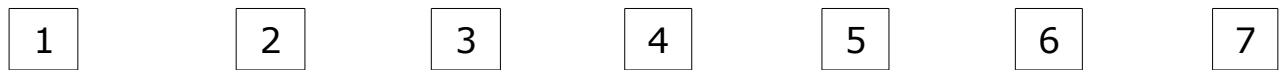

5. Workers achieve similar performance levels for all tasks.

\begin{tabular}{|l|l|l|l|l|l|}
\hline 1 & 2 & 3 & 4 & 5 & 6
\end{tabular}

b) Skill level of workers to perform different jobs.

1. Workers possess many different skills.

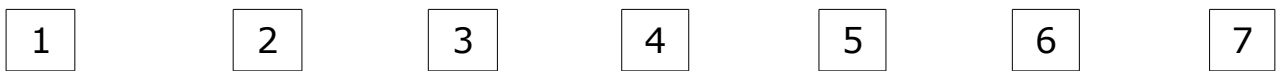

2. Workers can perform various types of tasks.

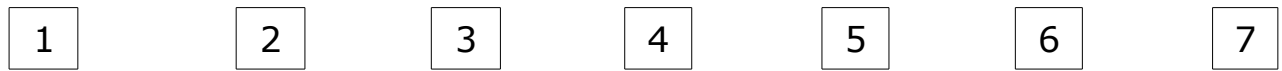

3. Workers can perform a large number of tasks.

\begin{tabular}{|c|c|}
\hline 1 & 2 \\
\hline
\end{tabular}

4. Workers can perform tasks which differ greatly from one another.

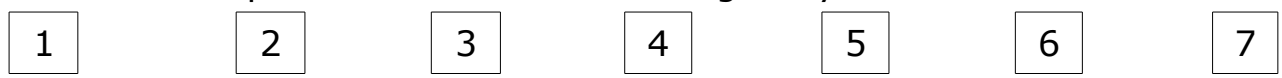

c) Cost effectiveness of workers over job change.

1. Worker choice does not affect the processing cost (in rupees) of a task.

\begin{tabular}{|c|c|c|}
\hline 1 & 2 & \\
\hline
\end{tabular}

2. Workers are equally efficient at all tasks.
1
23
4
5
6
7

3. A small cost is incurred (in rupees) when workers are moved between different tasks.

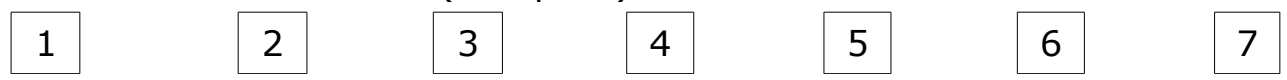

d) Reliability of workers over job change.

1. Workers are equally reliable for all tasks.
1

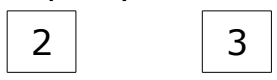
4

5
6
7

2. Workers are equally effective, in terms of quality, for all tasks.

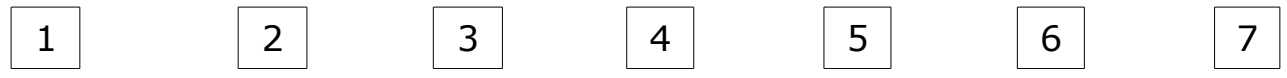

3. A short time delay occurs when workers are moved between different tasks.

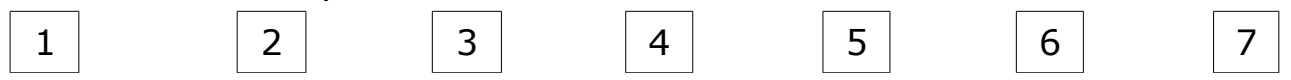


e) Attitude of workers towards change.

1. Workers show positive attitude towards change.
1
2
3
4
5
6
7

2. It is easy to move workers between different tasks.
1
2
3
4
5
6
7

f) Productivity effectiveness due to change of workforce.

1. A small cost is incurred (in terms of lost productivity) when workers are moved between different tasks.
1
23
4
5
6
7

2. Workers are equally effective, in terms of productivity, for all tasks.

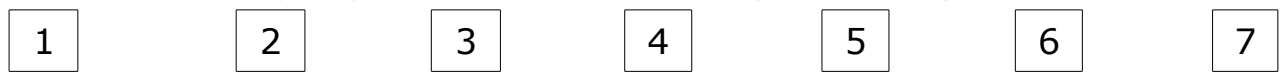

g) Co-operation of workers in achieving production targets.

1. Workers cooperate in achieving production targets.
1

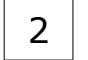
3
4
5

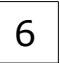
7

2. Workers can move easily between different tasks.
1
2
3
4
5
6
7

h) Ability of production workers to perform inspection jobs.

1. Production workers are able to perform inspection jobs.
1
2
3
4
5
6
7

i) Ability of production workers to do autonomous maintenance.

1. Production workers are able to do maintenance autonomously.
1
2
3
4
5
6
7

j) Training of workers.

1. Workers are cross-trained to perform many different tasks.

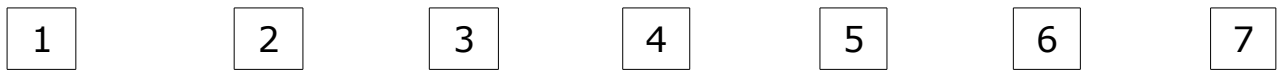

k) Ability of machines to perform diverse set of operations.

1. A typical machine can perform a high percentage of the total number of operations performed in the plant.
1
2
3
4
5
6 
2. A large number of operations can be performed by more than one machine.
1
2
3
4
5
6
7

3. A typical machine can use many different tools.
1
2
3
$4 \quad 5$
6
7

4. The number of different operations that a typical machine can perform is high.

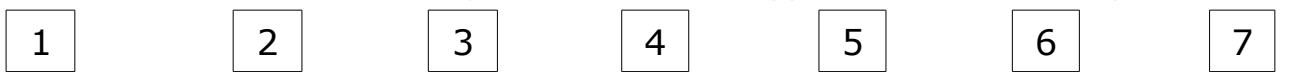

5. Machines can perform operations which are not very similar to one another.

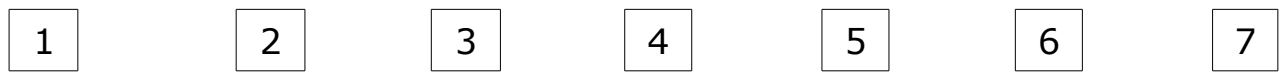

6. Machines can perform various types of operations.
1
23
4
5
6
7

7. Machines can perform a variety of operations.
1
2
3
4
5
6
7

8. Machines can perform operations which differ greatly from one another.

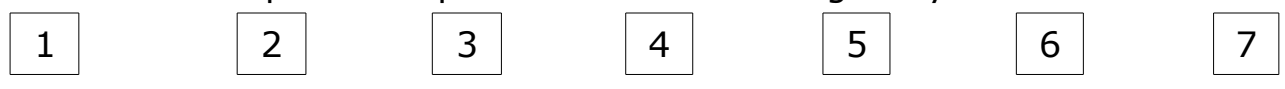

I) Machine setup or changeover.

1. Machine changeovers between operations are easy.
1
2
3
4
5
6
7

2. Machine set-ups between operations are quick.
1
2
3
4
5
6
7

3. Very low capacity is used in changing between machine operations.
1
2
3
4
5
6
7

m) Time and effort needed to change the tools and operations.

1. The effort in terms of time required is very low in switching from one operation to another.
1
2
3
4
5
6
7

2. Machine tools can be changed quickly.
1
2
3
4
5
6
7

n) Cost effectiveness of operations over machine change.

1. The processing cost (in rupees) of an operation is not affected by machine choice.
1
2
3
4
5
6 
2. The effort in terms of cost is very low in switching from one operation to another.
1
$2 \quad 3$
4
5
6
7

3. All machines achieve similar performance across all operations.

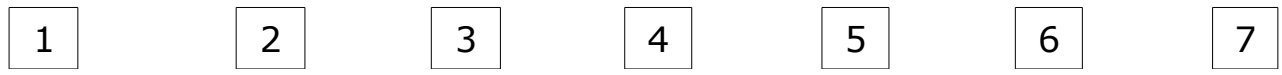

o) Productivity effectiveness due to change of machine.

1. Machines are equally effective, in terms of productivity, for all operations.
1
2
3
4
5
6
7

2. Machines are equally efficient for all processing operations.
1
2
3
4
5
6
7

3. Machines are equally effective, in terms of quality, for all operations.

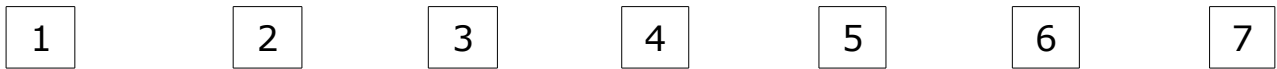

p) Obsolescence rate of machines on introduction of new products.

1. The machines don't become obsolete at a higher rate when new product is introduced.
1
2
3
4
5
6
7

2. Existing machines can be used to perform new operations.

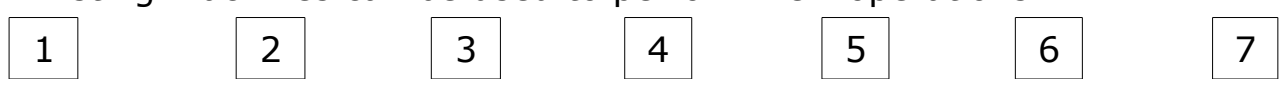

q) Reliability of machines over job change.

1. Machines are equally reliable for all operations.
1
2
3
4
6
7

2. Machines breakdown frequency doesn't increases due to rapid change in product and operators.
1
2
3
4
5
6
7

Journal of Industrial Engineering and Management, 2014 (www.jiem.org)

Article's contents are provided on a Attribution-Non Commercial 3.0 Creative commons license. Readers are allowed to copy, distribute and communicate article's contents, provided the author's and Journal of Industrial Engineering and Management's names are included. It must not be used for commercial purposes. To see the complete license contents, please visit http://creativecommons.org/licenses/by-nc/3.0/. 